\title{
Religious Orientation, Academic Stress and Religious Coping among First Year Undergraduate Students
}

\author{
Afaf Osman \\ Department of Educational Psychology \\ and Counseling, \\ Kulliyyah of Education, \\ International Islamic University Malaysia, \\ Kuala Lumpur, Malaysia \\ afaffly@gmail.com
}

\author{
Iman Osman Mukhtar Ahmed \\ Department of Educational Psychology \\ and Counseling, \\ Kulliyyah of Education, \\ International Islamic University Malaysia \\ Kuala Lumpur, Malaysia \\ imanosm@gmail.com
}

\begin{abstract}
The study aimed to assess the prevalence of religious orientation, academic stress, and the use religion as a means to cope with academic stress among first-year undergraduates. The sample consisted of 321 first year students from five faculties of a religiously oriented public university in Malaysia. The data were collected using three separated instruments: a Religious Coping Questionnaire, an Academic Stress Scale, and an Orientation Scale. Frequency analysis was used to examine the prevalence of stress, and religious orientation, while Pearson moment correlation was used to analyze the relationship among the three main constructs: religious coping, religious orientation and academic stress. The analysis ran an independent sample t-test to check for gender-differences in academic stress, religious coping and academic stress. The results showed high incidences of the religious orientation and religious coping among the sample of undergraduates, but no significant gender differences. The study substantiated that one of the means by which the first year students reduced their academic stress is through religious coping and religious orientation.
\end{abstract}

Keywords: Academic stress, religious coping, religious orientation, first-year undergraduate students, gender-differences

\section{INTRODUCTION}

Today's generation of students faces multiple problems in their daily lives and are influenced by the ever-changing environments and challenging situations. Among the challenges is the issue of academic stress. Academic stress among students has been investigated extensively by a massive number of studies. These studies concluded that there are countless reasons behind students' stress ((Amponsah, Adasi, Mohammed, Ampadu, \& Okrah, 2020). Assignments, examinations, failures, peer competition, lack of pocket money (Fairbtother \& Warn, 2003; Reddy, Menon, Thattil, 2018; Portoghese, \& et al., 2019), parental pressure, poor relationships with colleagues or lecturers, and poor time management, were found to be the most common sources of stressors among college students. While these are personal-level stressors, there are also institutional-level stressors such as overcrowded lecture halls, complicated registration procedures, and insufficient resources to accomplish academic work (Bataineh, 2013; Awino \& Agolla, 2008). 
Numerous studies have found that religion plays a vital role in coping with stress, depression and anxiety (Pargament, 1997; Ghaus, 2016; Yun, Kim, \& Awasu, 2019; Philip, Neuer-Colburn, Underwood, \& Bayne, 2019). In dealing with stressors, students may exploit a religious orientation as a defence mechanism to lower their levels of academic stress. Bataineh (2013) and Amponsah and et at. (2019) reported that religious coping is a better predictor of adjustment to challenging academic settings such as taking an examination, final project submission, and project defence, in comparison with general religious orientation. However, strategies employed in religious coping have produced disparate results in different stressful circumstances. Hence, research has found religious coping to be either harmful or helpful depending on the specific strategy developed (Krok, 2015; Parenteau, 2017).

To date, most studies on religious coping involving adolescents have been conducted in the West (Smith, McCullough, \& Poll, 2003; Hollinger, \& Timothy 2002). What we have in the extant literature hardly explains the prevalence of the phenomenon among Muslim student populations. Hence, this study was taken up to address this gap; focussing on a sample of Muslim students from a diversity cultures and backgrounds as those present within the student population of the Malaysian public university.

\section{LITERATURE REVIEW}

According to Miryala (2015), stress is “the body's reaction to a change that requires a physical, mental, or emotional adjustment or response" (p. 23). Feelings of stress in humans are a result of interaction between individuals and their environment that is perceived as a strain or more than their adaptive abilities can cope and threatening their well-being (). So, when there is a change in life conditions, people experience stress and they need to adapt to the new circumstance.

The academic environment is a challenging environment for students, as they are facing several types of stressors every day (Baqutayan, 2011). Students' stressors can be divided into five main types: personal, environmental, social and cultural, psychological, and academic. Environmental stress is related to university circumstances especially with first-year college students, such as homesickness, culture shock, etc. (Sajid, Ahmad, \& Khalid, 2015).

\section{Academic Sources of Stress}

Academic stress is considered the most substantial source of stress among students (Rao, 2008). Academic stressors include such factors as homework, preparation for tests, lack of interest in a specific subject, unsatisfactory academic performance, lower grades, and difficulty in understanding subject's contents (Sajid et al., 2015). As students link their academic achievement with their future, any changes in their academic performance can lead to a high level of stress (Siraj, Salam, Roslan, Hasan, Jin, \& Othman, 2014). 


\section{Stress and Religious Coping}

Coping strategy denotes a mechanism of coping adopted in a particular context. Over a period of time, the individual evolves a precise coping strategy. This refers to the manner in which an individual reacts to any stressful experience. According to Pargament (1985), religion plays three important roles with regard to coping with stress and strain: Firstly, as a part of coping components, secondly as a provider toward coping, and lastly as a product of coping. Several studies have been conducted on how religious orientation is instrumental to how students manage their stress (Radzi, Ramly, Ghazali, Sipon, \& Othman, 2014).

The main factor that influences the religious coping strategies is religious involvement. Adapting to difficult situations seemed to be highly predictable by religious coping compared to general religious orientation. Religion has regularly been cited as a coping strategy of dealing with both depressive moods and risk behaviours in adolescents. Several studies have been conducted to establish the fact that religion is one of the ways students could reduce stress. Meanwhile, studies about the relationship between religious and spiritual coping strategies and academic stressors that involved Muslim students revealed that there is a significant positive correlation between religiosity and academic stress. Students with strong religious personality showed mild to low stress levels (Bataineh, 2013; Radzi, \& et al., 2014). Students with high religious commitment have high levels of life satisfaction than students with low religious commitments (Waithaka \& Gough, 2017). Even studies conducted with non-Muslim student populations found that spirituality has a great effect on students' handling of stressors (Yun, \& et al., 2019). Similarly, Roming and Howard (2019) confirmed that spiritual growth was an essential adaptive factor among students, which contributed to a higher quality of life.

\section{Objectives of the Study}

The objectives of the present study were to survey the prevalence of religious orientation, religious coping and academic stress among first year students at a religiously oriented Malaysian public university and the prospective association among the three constructs. Primarily the study aimed to answer the following questions:

1. What are the levels of religious orientation, academic stress, and the use of religion as a means to cope with academic stress?

2. Are there any association among religious orientation, academic stress, and religious orientation?

3. Is there any gender difference in the use of religious coping among first year students? 


\section{METHODOLOGY}

\section{Research Design}

The present study is a quantitative exploratory research that uses a cross-sectional survey to collect the required data.

\section{Population and Sample}

The population comprises first year students from a Malaysian public university that has an Islamic religious orientation to its work culture, practice and procedures. The reason for choosing students from this university is that this university has a high influx of international students, and hence provides the study with a culturally diverse Muslim population for more robust results concerning responses to academic stress.

A quota sampling technique was used to select 321 first year undergraduate student respondents from the Faculties of Education, Engineering, Law, Human Sciences and Economics.

\section{Instruments}

Multi-item scales were adopted to measure the three constructs of the study. All items were drawn from existing scales with satisfactory reliabilities. Some of the questionnaire items were slightly modified to reflect the profile of first year students. The survey contains three separated scales and several demographic questions profiling the respondents on factors such as age, gender, nationality and faculty.

\section{Religious Orientation Scale (ROS)}

In this scale, Developed by Allport and Ross (1967) and later refined by Gorsuch and MacPherson (1989), religiosity is measured by intrinsic and extrinsic factors (see the Appendix). The reliability of the ROS using the Cronbach alpha varies from .78 to .87 .

\section{Educational Stress Scale for Adolescents (ESSA)}

The Educational Stress Scale for Adolescents (ESSA)is a 16-item scale developed by Sun, Dunne, Hou and Xu (2010). Seven items were adapted from the Academic Expectations Stress Inventory (AESI) (Ang \& Huan, 2006) with a 5-point Likert scale ranging from 1 (Strongly Disagree) to 5(Strongly Agree) (see the appendix). The Cronbach alpha of the 16-item ESSA scale was .81 , representing good internal consistency.

\section{Brief Religious Coping Scale (BRIEF RECOPE)}

The Brief RECOPE, was developed out of Pargament's (1997) program of theory and research on religious coping. The BRIFE RECOPE is a 14-item scale of religious coping with major life stressors. It is divided into two overarching forms of religious coping, i.e., positive and negative 
RECOPE (see the Appendix). Studies showed that the reliability of the RECOPE which is deemed important for internal consistency of the students' responses, exceeded the cut-off score, with alpha at .94 .

\section{Data Collection Procedure}

A quota sampling method was employed in order to get across to all the selected Kulliyyahs. The researcher distributed the questionnaire along with some volunteers across all the five Kulliyyahs (faculties), Law, Engineering, Human Science, Economics and Education. Data collection was conducted over a period of two weeks. Each student was asked to answer a set of questionnaires. All subjects were informed that their participation will be kept strictly confidential.

\section{RESULTS}

\section{Students' Religious Orientation}

Table 1 presents the first-year students' responses to statements related to religious orientation. The frequency (percentage) distributions of the responses showed that most students agreed that religion is particularly essential to them because it makes them relax when stressed (95\%), religion aids to maintain their life balanced and steady in the same way exactly as their friendship, citizenship, as well as other memberships do (92.8\%), the aim of prayer is to procure a happy and peaceful life $(92.2 \%)$.

Comparably, at least eight out of ten students agreed they would say their prayer when in stress, feeling that the objective of prayer is to secure relief and security. Similarly, distribution of agreements was observed for statements suggesting the importance of prayer [i.e., "prayers carry as much meaning and personal emotions when said alone as when offered in congregation," (83\%); "religion gives feelings of comfort during stress" (83\%); and "trying hard to integrate religion into all other life endeavours" (80.4\%). The influence of religion appears to be pervasive in this sample of undergraduates, where about $80 \%$ "find it important to spend time in private religious thought and meditation" and have "religious principles as the main driving force of their whole approach to life." Additionally, more than two thirds of the sample are often deeply aware of God's presence and recite the Holy Quran as a means of reducing stress. 


\section{Table 1}

Frequency (percentage) Distribution of Students' Religious Orientation

\begin{tabular}{|c|c|c|c|}
\hline Item & Disagree & Undecided & Agree \\
\hline $\begin{array}{l}\text { Religion is especially important to me because it } \\
\text { makes me relax when I am in stressful situation }\end{array}$ & $\begin{array}{c}3 \\
3 \\
(.9)\end{array}$ & $\begin{array}{l}13 \\
(4)\end{array}$ & $\begin{array}{l}305 \\
(95)\end{array}$ \\
\hline $\begin{array}{l}\text { Religion helps to keep my life balanced and steady } \\
\text { in exactly the same way as my citizenship, } \\
\text { friendship and other memberships do }\end{array}$ & $\begin{array}{c}5 \\
(1.6)\end{array}$ & $\begin{array}{c}18 \\
(5.6)\end{array}$ & $\begin{array}{c}297 \\
(92.8)\end{array}$ \\
\hline $\begin{array}{l}\text { The purpose of prayer is to secure a happy and } \\
\text { peaceful life. }\end{array}$ & $\begin{array}{c}8 \\
(2.5)\end{array}$ & $\begin{array}{c}17 \\
(5.3)\end{array}$ & $\begin{array}{c}296 \\
(92.2) \\
\end{array}$ \\
\hline Whenever I am in stress, I use to say my prayers & $\begin{array}{c}5 \\
(1.6)\end{array}$ & $\begin{array}{c}37 \\
(11.6)\end{array}$ & $\begin{array}{c}278 \\
(86.9)\end{array}$ \\
\hline $\begin{array}{l}\text { mary purpose of prayer is to gain relief and } \\
\text { on }\end{array}$ & $\begin{array}{c}10 \\
(3.1)\end{array}$ & $\begin{array}{c}41 \\
(12.8) \\
\end{array}$ & $\begin{array}{l}267 \\
(84)\end{array}$ \\
\hline $\begin{array}{l}\text { The prayers I say when I am alone carry as much } \\
\text { meaning and personal emotions as those said by me } \\
\text { during congregates }\end{array}$ & $\begin{array}{c}11 \\
(3.4)\end{array}$ & $\begin{array}{c}44 \\
(13.8)\end{array}$ & $\begin{array}{c}264 \\
(82.8)\end{array}$ \\
\hline $\begin{array}{l}\text { What religion offers me most is comfort when I am } \\
\text { in stress }\end{array}$ & $\begin{array}{c}11 \\
(3.5)\end{array}$ & $\begin{array}{c}44 \\
(13.9) \\
\end{array}$ & $\begin{array}{c}262 \\
(82.6) \\
\end{array}$ \\
\hline $\begin{array}{l}\text { to carry my religion over into all my other } \\
\text { in life }\end{array}$ & $\begin{array}{c}19 \\
(5.9)\end{array}$ & $\begin{array}{c}44 \\
(13.7)\end{array}$ & $\begin{array}{c}258 \\
(80.4) \\
\end{array}$ \\
\hline $\begin{array}{l}\text { to me to spend periods of time in } \\
\text { us thought and meditation }\end{array}$ & $\begin{array}{c}9 \\
(2.8)\end{array}$ & $\begin{array}{c}55 \\
(17.2)\end{array}$ & $\begin{array}{l}256 \\
(80)\end{array}$ \\
\hline $\begin{array}{l}\text { My religious beliefs are what really lie behind my } \\
\text { whole approach to life }\end{array}$ & $\begin{array}{l}11 \\
(3.5)\end{array}$ & $\begin{array}{c}50 \\
(16.1)\end{array}$ & $\begin{array}{c}250 \\
(80.4)\end{array}$ \\
\hline $\begin{array}{l}\text { I use to read the holy Quran when I want to reduce } \\
\text { my stress }\end{array}$ & $\begin{array}{c}13 \\
(4.1)\end{array}$ & $\begin{array}{c}57 \\
(17.9)\end{array}$ & $\begin{array}{c}249 \\
(78.1)\end{array}$ \\
\hline $\begin{array}{l}\text { Quite often I am keenly aware of the presence of } \\
\text { God }\end{array}$ & $\begin{array}{c}22 \\
(6.9)\end{array}$ & $\begin{array}{c}50 \\
(15.8)\end{array}$ & $\begin{array}{c}245 \\
(77.3)\end{array}$ \\
\hline $\begin{array}{l}\text { Occasionally I find it necessary to compromise my } \\
\text { religious beliefs in order to cope with my everyday } \\
\text { stress }\end{array}$ & $\begin{array}{c}41 \\
(13.2)\end{array}$ & $\begin{array}{c}64 \\
(20.6)\end{array}$ & $\begin{array}{c}206 \\
(66.2)\end{array}$ \\
\hline $\begin{array}{l}\text { Listening to religious music makes me relax when I } \\
\text { am in tension }\end{array}$ & $\begin{array}{c}38 \\
(11.9)\end{array}$ & $\begin{array}{c}86 \\
(26.9)\end{array}$ & $\begin{array}{c}196 \\
(61.3)\end{array}$ \\
\hline $\begin{array}{l}\text { Although I believe in my religion, I feel there are } \\
\text { many other ways to solve my problem }\end{array}$ & $\begin{array}{c}133 \\
(41.4)\end{array}$ & $\begin{array}{c}82 \\
(25.8)\end{array}$ & $\begin{array}{c}103 \\
(32.4)\end{array}$ \\
\hline $\begin{array}{l}\text { It does not matter what I believe as long as I do not } \\
\text { have a problem }\end{array}$ & $\begin{array}{c}193 \\
(60.1) \\
\end{array}$ & $\begin{array}{c}66 \\
(20.6) \\
\end{array}$ & $\begin{array}{c}62 \\
(19.3) \\
\end{array}$ \\
\hline $\begin{array}{l}\text { Although I am a religious person, I refuse to let } \\
\text { religious considerations influence my stressful } \\
\text { events }\end{array}$ & $\begin{array}{c}144 \\
(45.6)\end{array}$ & $\begin{array}{c}112 \\
(35.4)\end{array}$ & $\begin{array}{c}60 \\
(19)\end{array}$ \\
\hline
\end{tabular}

The respondents reported they occasionally compromised their religious beliefs in order to cope with everyday stress $(66.2 \%)$ and listened to religious music to make them feel more relaxed during difficult situations (61.3\%). 61\% agreed that listening to religious music makes them relax when tensed. A substantial proportion disagreed that religion does not matter as long as their lives are free from problems and issues (60.1\%). 
It can be deduced from the results of data analysis that most of the responses (80\%) were positively skewed to "agree", especially from those items which represent positive religious orientations, thereby indicating that most of the respondents have a positive religious orientation. However, the last five items, which represented negative religious orientations, showed the responses were negatively skewed towards "disagree," which indicated that most students disagreed with the negative religious orientation. Therefore, it can be concluded that most of the first year students in selected religiously oriented public university in Malaysia have positive religious orientations.

\section{Students’'Academic Stress}

Table 2 shows the students' level of academic stress caused by parental pressures, as most students are highly stressed when they disappoint their parents $(68.8 \%)$. The second highest stressor is academic performance, "the students' academic grades could impact their future and even can determine their whole life" (59.1\%). The third stressor for the respondent sample was "too many tests/exams in the school led to high levels of stress among students $(56.6 \%)$ ". "Teacher disappointed when students' test/exam results are not ideal" (55.9\%) was ranked as the fourth stress source for the students. Future education and career appears to be among the highest academic pressure (50.5\%). Moreover, $49.2 \%$ of the participants were "not satisfied with their academic grades", and a similar percentage showed moderate stress (43.6\%).

Table 2

Frequency (percentage) Distribution of Students' Academic Stress

\begin{tabular}{lccc}
\hline \multicolumn{1}{c}{ Item } & No & Moderate & High \\
& Stress & Stress & Stress \\
\hline I feel that I have disappointed my parents when my & 7 & 93 & 221 \\
test/exam results are poor & $(2.2)$ & $(29)$ & $(68.8)$ \\
\hline When I fail to live up to my own expectations, I & 9 & 122 & 189 \\
feel I am not good enough & $(2.8)$ & $(38.1)$ & $(59.1)$ \\
\hline I feel stressed when I do not live up to my own & 12 & 126 & 180 \\
standards & $(3.7)$ & $(39.6)$ & $(56.6)$ \\
\hline Academic grade is very important to my future and & 9 & 132 & 179 \\
even can determine my whole life & $(2.8($ & $(41.3)$ & $(55.9)$ \\
\hline I feel that there are too many tests /exams in the & 11 & 148 & 162 \\
school & $(3.4)$ & $(46.1)$ & $(50.5)$ \\
\hline I feel that I have disappointed my teacher when my & 23 & 140 & 158 \\
test/exam results are not ideal & $(7.2)$ & $(43.6)$ & $(49.2)$ \\
\hline Future education and employment bring me a lot & 11 & 152 & 156 \\
of academic pressure & $(3.4)$ & $(47.6)$ & $(48.9)$ \\
\hline I am very dissatisfied with my academic grades & 15 & 156 & 149 \\
& $(4.7)$ & $(48.8)$ & $(46.6)$ \\
\hline I always lack confidence with my academic scores & 18 & 153 & 149 \\
& $(5.6)$ & $(47.8)$ & $(46.6)$ \\
\hline I feel a lot of pressure in my daily studying & 10 & 168 & 143 \\
& $(3.1)$ & $(52.3)$ & $(35.5)$ \\
\hline There is too much competition among classmates & 19 & 161 & 141 \\
which brings me a lot of academic pressure & $(5.9)$ & $(50.2)$ & $(43.9)$ \\
\hline
\end{tabular}


Table 2

Continued

\begin{tabular}{lccc}
\hline \multicolumn{1}{c}{ Item } & $\begin{array}{c}\text { No } \\
\text { Stress }\end{array}$ & $\begin{array}{c}\text { Moderate } \\
\text { Stress }\end{array}$ & $\begin{array}{c}\text { High } \\
\text { Stress }\end{array}$ \\
\hline I feel that there is too much school work & 16 & 177 & 128 \\
& $(5)$ & $(55.1)$ & $(39.9)$ \\
\hline I feel there is too much homework & 18 & 179 & 123 \\
& $(5.6)$ & $(55.9)$ & $(38.4)$ \\
\hline I usually cannot sleep and worry when I cannot & 40 & 161 & 120 \\
meet the goals I set for myself & $(12.5)$ & $(50.2)$ & $(37.4)$ \\
\hline My parents care about my academic grades too & 45 & 176 & 100 \\
much which brings me a lot of pressure & $(14)$ & $(54.8)$ & $(31.2)$ \\
\hline
\end{tabular}

Other sources of academic stressors such as "lack confidence with academic scores"; "feeling of a lot of pressure during the daily studying"; "high competition among classmates", were stress pressures among the first year students, with about average percentage of $47 \%$. However, half of the respondents have moderate levels of stress with regard to concentration in the class, homework, parents' pressure and ability to accomplish their goals.

An inspection of the outcomes reveals that a maximum number of the responses fall between the high stress and moderate stress, while the very low responses fall within the no stress option. What can be inferred from this is that academic stress is common among first year undergraduate students, as indicated by the generally low scores for 'no stress'. The item with the highest response is parent expectation indicating that students are stressed by continuous feelings of concern about their parents' expectations.

\section{Use of Religion as a Means to Cope with Academic Stress}

Table 3 presents the frequency (percentage) distributions of how the students responded to academic stress through religious coping strategies. The majority of first year students $(98.2 \%)$ ask forgiveness for their sins (moderate and great deal), seek the love of God and care (99\%), search for a higher connection with God (97\%), seek help from God to curb their anger (97.2\%), strived to see how God might assist them in their predicament (91\%), decided that their destiny was fated $(88.7 \%)$, engrossed on religion and stop distressing about their difficulties $(89.1 \%)$, and felt chastised by God due to lack of their religious commitment $(71.7 \%)$, in response to the state of their academic stress. These are the religiously positive responses to stress, which would ultimately reduce their stress. 
Table 3

Frequency (percentage) Distribution of Students' Religious Coping

\begin{tabular}{|c|c|c|c|c|}
\hline Item & $\begin{array}{c}\text { Not at } \\
\text { all }\end{array}$ & A little & Moderate & $\begin{array}{c}\text { A great } \\
\text { deal }\end{array}$ \\
\hline Asked forgiveness for my sins & $\begin{array}{c}1 \\
(.3)\end{array}$ & $\begin{array}{c}5 \\
(1.6) \\
\end{array}$ & $\begin{array}{c}48 \\
(15)\end{array}$ & $\begin{array}{c}267 \\
(83.2) \\
\end{array}$ \\
\hline Sought God's love and care & $\begin{array}{c}0 \\
(0)\end{array}$ & $\begin{array}{c}1 \\
(.3)\end{array}$ & $\begin{array}{c}74 \\
(23.1)\end{array}$ & $\begin{array}{c}246 \\
(76.6)\end{array}$ \\
\hline $\begin{array}{l}\text { Looked for a stronger connection with } \\
\text { God }\end{array}$ & $\begin{array}{c}0 \\
(0)\end{array}$ & $\begin{array}{l}3 \\
(.9)\end{array}$ & $\begin{array}{c}81 \\
(25.2)\end{array}$ & $\begin{array}{c}237 \\
(73.8)\end{array}$ \\
\hline $\begin{array}{l}\text { Sought help from God in letting go of } \\
\text { my anger }\end{array}$ & $\begin{array}{c}1 \\
(.3)\end{array}$ & $\begin{array}{c}8 \\
(2.5) \\
\end{array}$ & $\begin{array}{c}113 \\
(35.2)\end{array}$ & $\begin{array}{l}199 \\
(62)\end{array}$ \\
\hline $\begin{array}{l}\text { Tried to see how God might be trying } \\
\text { to strengthen me in this situation }\end{array}$ & $\begin{array}{c}7 \\
(2.2)\end{array}$ & $\begin{array}{l}16 \\
(5)\end{array}$ & $\begin{array}{c}98 \\
(30.9)\end{array}$ & $\begin{array}{c}196 \\
(61.8)\end{array}$ \\
\hline $\begin{array}{l}\text { Tried to put my plans into action } \\
\text { together with God }\end{array}$ & $\begin{array}{c}1 \\
(.3)\end{array}$ & $\begin{array}{c}7 \\
(2.2)\end{array}$ & $\begin{array}{c}114 \\
(36.1)\end{array}$ & $\begin{array}{c}194 \\
(60.4)\end{array}$ \\
\hline Decided my destiny made this happen & $\begin{array}{c}13 \\
(4.1)\end{array}$ & $\begin{array}{c}22 \\
(6.9)\end{array}$ & $\begin{array}{c}92 \\
(28.7)\end{array}$ & $\begin{array}{c}193 \\
(60.3)\end{array}$ \\
\hline $\begin{array}{l}\text { Focused on religion to stop worrying } \\
\text { about my problems }\end{array}$ & $\begin{array}{c}2 \\
(.6)\end{array}$ & $\begin{array}{c}33 \\
(10.3) \\
\end{array}$ & $\begin{array}{c}156 \\
(48.8)\end{array}$ & $\begin{array}{c}129 \\
(40.3)\end{array}$ \\
\hline $\begin{array}{l}\text { Felt punished by God for my lack of } \\
\text { devotion }\end{array}$ & $\begin{array}{l}29 \\
(9)\end{array}$ & $\begin{array}{c}61 \\
(19) \\
\end{array}$ & $\begin{array}{c}126 \\
(39.3)\end{array}$ & $\begin{array}{c}104 \\
(32.4)\end{array}$ \\
\hline $\begin{array}{l}\text { Wondered what I did for God to punish } \\
\text { me }\end{array}$ & $\begin{array}{c}55 \\
(17.2)\end{array}$ & $\begin{array}{c}69 \\
(21.6) \\
\end{array}$ & $\begin{array}{c}115 \\
(36.1)\end{array}$ & $\begin{array}{c}80 \\
(25.1)\end{array}$ \\
\hline $\begin{array}{l}\text { Wondered whether God has abandoned } \\
\text { me }\end{array}$ & $\begin{array}{c}109 \\
(34.4)\end{array}$ & $\begin{array}{c}80 \\
(25.2) \\
\end{array}$ & $\begin{array}{c}72 \\
(22.7) \\
\end{array}$ & $\begin{array}{c}56 \\
(17.7) \\
\end{array}$ \\
\hline Questioned God's mercy for me & $\begin{array}{c}126 \\
(39.3)\end{array}$ & $\begin{array}{c}72 \\
(22.4)\end{array}$ & $\begin{array}{c}72 \\
(22.4)\end{array}$ & $\begin{array}{c}51 \\
(15.9)\end{array}$ \\
\hline Questioned God's love for me & $\begin{array}{c}123 \\
(38.3)\end{array}$ & $\begin{array}{c}83 \\
(25.9) \\
\end{array}$ & $\begin{array}{c}75 \\
(23.4)\end{array}$ & $\begin{array}{c}39 \\
(12.2)\end{array}$ \\
\hline Questioned the power of God & $\begin{array}{c}207 \\
(65.1)\end{array}$ & $\begin{array}{c}36 \\
(11.3)\end{array}$ & $\begin{array}{c}37 \\
(11.6)\end{array}$ & $\begin{array}{c}38 \\
(11.9)\end{array}$ \\
\hline
\end{tabular}

On the other hand, some (55\%) of respondents wondered what they did to deserve punishment (57\%), wondered whether God has abandoned them (slightly) (59.2\%), questioned the mercy of God (61.7\%), questioned God's love for them (72.9\%) and questioned the power of God (76.4\%) in response to the stress the students experienced. One could see that these last five items are direct opposites of the above items. The results indicated that most of the respondents exhibited positive use of religious coping towards their academic stress, even though the responses were negative.

\section{Relationship among Religious Coping, Religious Orientation and Academic Stress}

Pearson's product-moment correlation coefficient was estimating the relationship of religious coping, academic stress and religious orientation among first year students. The results show a positive significance but very weak correlation between the religious coping and academic stress $\mathrm{r}=0.191, \mathrm{p}=0.01$. Relatively, there was a slightly stronger and significant correlation between religious coping and religious orientation $r=0.39, p=0.01$. Meanwhile, the correlation between religious orientation and academic stress was also significant, albeit weak $(=0.22, p=0.01)$. These results indicate that there is little relationship between academic stress as well as both religious 
coping and religious orientation. What can be deduced here is that academic stress is normal for serious minded students, but being religious would keep stress manageable.

\section{Gender Differences in Religious Coping and Academic Stress}

Table 4 sheds light on gender differences on religious coping and academic stress among first year students in selected public university. The table presents the result for the difference in gender in relation to religious coping, academic stress and religious orientation. It shows no significant difference in the score for males on religious coping $(\mathrm{M}=2.03, \mathrm{SD}=.43)$, academic stress $(\mathrm{M}=3.35, \mathrm{SD}-.74)$ and religious orientation $(\mathrm{M}=3.84, \mathrm{SD}=.48)$ as well as females in terms of religious coping $(\mathrm{M}=2.04, \mathrm{SD}=.39)$, academic stress $(\mathrm{M}=3.43, \mathrm{SD} .69)$ and religious orientation $(\mathrm{M}=3.92, \mathrm{SD}=.38)$. While $\mathrm{t}(297)=-.13, \mathrm{p}=.89 ; \mathrm{t}(309)=-.78, \mathrm{p}=.44 ;$ and $\mathrm{t}$ $(289)=-1.77, p=.09$ for religious coping, academic stress, and religious orientation, respectively.

Table 4

Gender-Differences in Religious Coping, Academic Stress and Religious Orientation of First Years Students

\begin{tabular}{llccccc}
\hline Variable & Gender & Number & Mean & $\begin{array}{c}\text { STD } \\
\text { Deviation }\end{array}$ & t-value & Sig (2 tailed) \\
\hline $\begin{array}{l}\text { Religious } \\
\text { coping }\end{array}$ & Male & 93 & 2.03 & .43 & & \\
& Female & 206 & 2.04 & .39 & -.13 & .89 \\
$\begin{array}{l}\text { Academic } \\
\text { Stress }\end{array}$ & Male & 99 & 3.35 & .73 & & \\
& Female & 212 & 3.42 & .68 & -.78 & .43 \\
$\begin{array}{l}\text { Religious } \\
\text { Orientation }\end{array}$ & Male & 94 & 3.83 & .48 & & \\
& Female & 197 & 3.92 & .38 & -1.77 & .07 \\
\hline
\end{tabular}

\section{DISCUSSION AND CONCLUSION}

The result from the descriptive analysis shows that first year students mostly used religious means of coping for their stress relief. They agreed and strongly believed that religious rituals such as praying and reciting the glorious Quran greatly relieved them from academic stress. For this reason, they continuously referred to it when stressed. In support of this, studies have found that one potential mediator of the stress/depression relationship is religiosity, which has been associated with a protective (and rarely a risk factor) factor in the mental health discipline (Roming \& Howard, 2019; Ano \& Vasconcelles, 2005; Hackney \& Sanders, 2003; Harrison, Koenig, Hays, Eme-Akwari, \& Pargament, 2001). The rationale behind the positive influence of religious coping as well as religiosity on academia lies in the fact that Islam offers acts of worship that soothe the mind. For instance, before you can pray you clean your body with cool water, free your mind from all troubles and worries by purging the stressful tendencies in oneself through ablution. 
The data also revealed a positively significant (albeit weak) association between religious coping and students' academic stress, which implies a strong correlation between religious orientation and academic stress reduction. Bataineh (2013) conducted a similar study and discovered that there were positive relationships between religious sources and academic stress. This does not mean that religious coping and religious orientation are negative and cannot relieve individuals from stress.

The truth of the matter is that stress is something common for every normal and active human. This means that the presence of religiosity does not prevent human beings from becoming stressed. That is, religious coping can only moderately help academic stress but cannot remove it totally. Carpenter et al. (2012) found that positive religious coping only slightly reduced or weakened the effects of stress on depressive symptoms. Human beings learn how to cope and moderate stressful conditions through religious practices. Equally, stressors are live experiences that produce stress and can be either positive or negative. That is, life without stress does not exist, but the ability to manage, moderate and maintain it is what matters most, which is the function of religious coping and religious orientation.

The third finding from the present research is that there is no significant gender difference with regard to both academic stress and religious coping. Gender is not one of the determining factors that could positively or negatively influence religious coping or academic stress (Radzi, \& et al., 2014; Gardner, Krägeloh, \& Henning, 2014). This result is contrary to the findings of Sharma and Kaur (2011), who found that girls scored significantly higher overall on academic stress as compared to boys. This clearly indicates that there is gender difference with regard to academic stress. Equally, Backović, Živojinović, Maksimović, and Maksimović (2012), postulated that female students assessed their physical health status and overall stress status worse compared to males.

However, other studies found no significant gender difference with regard to academic stress, in support of this present research. For example, Farhan and Khan (2015) discovered that gender has no significant impact on students' GPA, level of stress and self-esteem. Bhosale (2014) asserted that there is no significant difference between boys and girls on academic stress and academic conflict. The author concluded that gender difference is not a key point in academic stress and academic conflict.

The major factor which could be responsible for the disparities in the findings of these scientific researches with the same variables could be the difference in cultural backgrounds. Socio-cultural backgrounds greatly influence human dispositions. It could be rationalised that those societies where gender is not considered a significant criterion for discrimination, will more likely treat different genders more equitably, whereas societies where gender is conflated with identity would possibly discriminate individuals based on their gender. Based on this, one could not conclusively conclude that both sides are scientifically untenable. However, the result from the present research suggests that gender is not a factor, meaning that there is no significant gender difference with regard to their academic stress and religious coping.

From the results derived from the present research, the researcher hereby recommends that students should take their religious orientation, understanding and orientation very 
seriously because it goes a long way in assisting them in coping with their academic stress and preventing severe stress which could lead to depression. Students are equally encouraged to become involved in religious activities in and outside the campus, for their religious understanding will improve, thereby having good religious orientation.

It is highly recommended for the university to regularly organise stress management orientation, which should include religious coping for first year students since it is a major problem that leads to other problems for students. It is impactful for higher institutions to organize relaxing, soothing, and spiritual programs for the students. 


\section{REFERENCES}

Allport, G. W., \& Ross, J. M. (1967). Personal religious orientation and prejudice. Journal of personality and social psychology, 5(4), 432.

Amponsah, K. D., Adasi, G. S., Mohammed, S. M. Ampadu, E. \& Okrah, A. K. (2020). Stressors and coping strategies: The case of teacher education students at University of Ghana. Cogent Education, 7(1), 1-17. DOI:10.1080/2331186X.2020.1727666

Ang R. P., \& Huan V.S. (2006). Academic Expectations Stress Inventory (AESI): development, factor analysis, reliability and validity. Educ Psychol Meas 66:522-539

Ano, G. G., \& Vasconcelles, E. B. (2005). Religious coping and psychological adjustment to stress: A metaanalysis. J. Clin. Psychol, 61: 1-20.

Awino, J. O., \& Agolla, J. E. (2008). A quest for sustainable quality assuranceMeasurementfor universities: case of study of the University of Botswana, Educ. Res. Rev. 3 (6): 213-218.

Backović, D. V., Živojinović, J. I., Maksimović, J., \& Maksimović, M. (2012). Gender differences in academic stress and burnout among medical students in final years of education. Psychiatria Danubina, 24(2), 175-181.

Baqutayan, S. M. S. (2011). The Importance of Religious Orientation in Managing Stress. International Journal of Psychology Study, 3(1), 113-121. doi:10.5539/ijps.v3n1p113

Bataineh, M. Z. (2013). Academic Stress Among Undergraduate Students: The Case of Education Faculty at King Saud University. International Interdisciplinary Journal of Education, 2(1), 82-88.

Bhosale U. V., (2014). A Study of Academic Stress and Gender Difference. Indian Streams Research Journal, Vol. IV, Issue. VI, DOI : 10.9780/22307850, http://isrj.org/ Uploaded Data/5101.pdf

Carpenter, T. P., Laney, T., \& Mezulis, A. (2012). Religious coping, stress, and depressive symptoms among adolescents: A prospective study. Psychology of Religion and Spirituality, 4(1), 19-30. doi:10.1037/a0023155

Farhan, S., \& Khan, I. (2015). Impact of Stress, Self-Esteem and Gender Factor on Students' Academic Achievement. International Journal on New Trends in Educational and Their Implication, 6(2), 143-156.

Fairbrother, K., \& Warn, J. (2003). Workplace dimensions, stress and job satisfaction. Journal of managerial psychology, 18(1), 8-21.

Gardner, T. M., Krägeloh, C. U., \& Henning, M. a. (2014). Religious coping, stress, and quality of life of Muslim university students in New Zealand. Mental Health, Religion \& Culture, 17(4), 327-338. doi:10.1080/13674676.2013.804044

Ghaus, A. (2016). Underlying dimensions and predictors of elderly happiness: an exploratory study of Rumah Seri Kenangan residents in West Malaysia, Doctoral dissertation. Kulliyyah of Education, International Islamic University Malaysia Kuala Lumpur. 
Hackney, C. H., \& Sanders, G. S. (2003). Religiosity and mental health: A meta-analysis of recent studies. Journal for the Scientific Study of Religion, 42, 43-55. doi:10.1111/14685906.t01-1-00160 Hammen.

Harrison, M. O., Koenig, H. G., Hays, J. C., Eme- Akwari, A. G., \& Pargament, K. I. (2001). The epidemiology of religious coping: A review of recent literature. International Review of Psychiatry, 13, 86-93. doi:10.1080/09540260120037317

Hollinger, F., \& Timothy, B. S. (2002). Religion and esotericism among students: A crosscultural comparative study. Journal of Contemporary Religion 17(2):229-49.

Krok, D. (2015). The Role of Meaning in Life Within the Relations of Religious Coping and Psychological Well-Being. Journal of Religion and Health, 54, 2292-2308. DOI 10.1007/s10943-014-9983-3

Miryala, R.K. (2015). Trends, challenges \& innovations in management. Zenon Academic Publishing. https://books.google.com/books?isbn=8192681998

Parenteau, S. C. (2017). Religious Coping and Substance Use: The Moderating Role of Sex. J Relig Health 56, 380-387. https://doi.org/10.1007/s10943-015-0166-7

Pargament, K. I. (1985). God help me: Toward a theoretical frame work of coping forthe psychology of religion. Journal for the Scientific Study of Religion, 2, $195-224$.

Pargament K.I. (1997). The psychology of religion and coping: theory, research and practice. Guildhall Press, London.

Pragament, K., Feuille, M., \& Burdzy, D. (2011). The Brief RCOPE: Current Psychometric Status of a Short Measure of Religious Coping Religions, 2, 51-76. www.mpdi.com /journal/religions

Philip, S., Neuer-Colburn, A. A., Underwood, L., \& Bayne, H. (2019). The impact of religion/spirituality on acculturative stress among international students. Journal of college Counseling, 22(1), 27- 40. https://doi.org/10.1002/jocc.12112

Portoghese, I., Galletta, M., Porru, F., Burdorf, A., Sardo, S., D’Aloja1, E., Finco, G., \& Campagna, M. (2019). Stress among university students: factorial structure and measurement invariance of the Italian version of the Effort-Reward Imbalance student questionnaire. BMC Psychology, 7, Article no. (68). https://doi.org/10.1186/s40359-0190343-7

Radzi, H. M., Ramly, L. Z., Ghazali, F., Sipon, S., \& Othman, K. (2014). Religious and spiritual coping used by student in dealing with stress and anxiety. International Journal of Asian Social Science, 4(2), 314-319.

Rao, A. S. (2008). Academic stress and adolescent distress: the experiences of $21^{\text {th }}$ standard students in chennai, india. Norton school of family and consumer sciences.

Reddy K. J, Menon K. R, Thattil A. (2018). Academic Stress and its Sources Among University Students. Biomed Pharmacol J ;11(1), 531-537.

Roming, S., \&_Howard, K. (2019). Coping with stress in college: an examination of spirituality, social support, and quality of life. Mental Health, Religion \& Culture, 22(8), 832-843 https://doi.org/10.1080/13674676.2019.1674794 
Sajid A., Ahmad T., \& Khalid T. (2015). Stress in medical undergraduates; its association with academic performance. Bangladesh Journal of Medical Science, 14(2), 135-141. DOI: http://dx.doi.org/10.3329/bjms.v14i2.21815

Sharma, N. \& Kaur, A. (2011). Factors associated with stress among nursing students. Nursing and Midwifery Research Journal, Vol-7, No. 1

Siraj, H.H., Salam, A., Roslan, R., Hasan, N.A., Jin, T.H., \& Othman, M.N. (2014). Stress and its association with the academic performance of undergraduate fourth year medical students at Universiti Kebangsaan Malaysia. International Medical Journal Malaysia, 13 (1), 19-24.

Smith, T. B., McCullough, M. E., \& Poll, J. (2003). Religiousness and Depression: Evidence for a main effect and a moderating influence of stressful life events. Psychological Bulletin, 129, 614-636.

Sun, Dune, Hou and $\mathrm{Xu}$ (2010). Educational Stress Scale for Adolescents: Development,Validity, and Reliability with Chinese Students. Journal of Psychoeducational Assessment.

Waithaka, A., \& Gough, D. M. (2017). The Influence of Religion on Stress and Coping of College Students. International Journal of Novel Research in Education and Learning, 4(1), 27-40. www.noveltyjournals.com

Yun, K., Kim, S., \& Awasu, C. R. (2019). Stress and impact of spirituality as a mediator of coping methods among social work college students. Journal of Human Behavior in the Social Environment, 29(1), 125-136. 


\section{APPENDIX I}

\section{Religious Orientation Questionnaire (Allport \& Ross, 1963)}

The following questions relate to different religious orientations that people believe. Read each statement carefully and indicate your agreement or disagreement with it. Indicate to the left of the statement the number that best describes how you think.

1=Strongly disagree, 2= Disagree, 3= Undecided, 4= Agree, 5= Strongly agree

\begin{tabular}{|c|c|c|c|c|c|c|}
\hline No & Statement & 1 & 2 & 3 & 4 & 5 \\
\hline 1. & $\begin{array}{l}\text { I try hard to carry my religion over into all my other } \\
\text { dealings in life. }\end{array}$ & & & & & \\
\hline 2. & Quite often I am keenly aware of the presence of God. & & & & & \\
\hline 3. & $\begin{array}{l}\text { Religion helps to keep my life balanced and steady in } \\
\text { exactly the same way as my citizenship, friendship } \\
\text { and other memberships do }\end{array}$ & & & & & \\
\hline 4. & $\begin{array}{l}\text { My religious beliefs are what really lie behind my } \\
\text { whole approach to life. }\end{array}$ & & & & & \\
\hline 5. & $\begin{array}{l}\text { The prayers I say when I am alone carry as much } \\
\text { meaning and personal emotions as those said by me } \\
\text { during congregates. }\end{array}$ & & & & & \\
\hline 6. & $\begin{array}{l}\text { Religion is especially important to me because it } \\
\text { makes me relax when I am in stressful situation }\end{array}$ & & & & & \\
\hline 7. & $\begin{array}{l}\text { It is important to me to spend periods of time in private } \\
\text { religious thought and meditation. }\end{array}$ & & & & & \\
\hline 8. & $\begin{array}{l}\text { The purpose of prayer is to secure a happy and } \\
\text { peaceful life. }\end{array}$ & & & & & \\
\hline 9. & $\begin{array}{l}\text { It does not matter what I believe as long as I do not } \\
\text { have a problem }\end{array}$ & & & & & \\
\hline 10. & $\begin{array}{l}\text { Although I am a religious person, I refuse to let } \\
\text { religious considerations influence my stressful events }\end{array}$ & & & & & \\
\hline 11. & $\begin{array}{l}\text { Although I believe in my religion, I feel there are } \\
\text { many other ways to solve my problem }\end{array}$ & & & & & \\
\hline 12. & $\begin{array}{l}\text { The primary purpose of prayer is to gain relief and } \\
\text { protection. }\end{array}$ & & & & & \\
\hline 13. & $\begin{array}{l}\text { Occasionally I find it necessary to compromise my } \\
\text { religious beliefs in order to cope with my everyday } \\
\text { stress. }\end{array}$ & & & & & \\
\hline 14. & $\begin{array}{l}\text { What religion offers me most is comfort when I am in } \\
\text { stress. }\end{array}$ & & & & & \\
\hline 15. & Whenever I am in stress, I use to say my prayers. & & & & & \\
\hline 16. & $\begin{array}{l}\text { I use to read the holy Quran when I want to reduce my } \\
\text { stress. }\end{array}$ & & & & & \\
\hline 17. & $\begin{array}{l}\text { Listening to religious music makes me relax when I } \\
\text { am in tension. }\end{array}$ & & & & & \\
\hline
\end{tabular}




\section{APPENDIX II}

\section{BRIEF RCOPE (Pargament, 1997)}

The following questions measure religious coping strategies. Please read each statement carefully and choose your response from the four options given below. Indicate to the left of the statement the number that best describes how you think.

$0=$ Not at all, $1=A$ little, 2= Moderate, $3=$ A great deal

\begin{tabular}{|l|l|l|l|l|l|}
\hline No & \multicolumn{1}{|c|}{ Statement } & 0 & 1 & 2 & 3 \\
\hline 1. & Looked for a stronger connection with God. & & & & \\
\hline 2. & Sought God's love and care. & & & & \\
\hline 3. & Sought help from God in letting go of my anger & & & & \\
\hline 4. & Tried to put my plans into action together with God. & & & & \\
\hline 5. & $\begin{array}{l}\text { Tried to see how God might be trying to strengthen me in } \\
\text { this situation. }\end{array}$ & & & \\
\hline 6. & Asked forgiveness for my sins. & & & & \\
\hline 7. & Focused on religion to stop worrying about my problems. & & & & \\
\hline 8. & Wondered whether God has abandoned me. & & & & \\
\hline 9. & Felt punished by God for my lack of devotion. & & & & \\
\hline 10. & Wondered what I did for God to punish me. & & & & \\
\hline 11. & Questioned God's love for me. & & & & \\
\hline 12. & Questioned God's mercy for me. & & & & \\
\hline 13. & Decided my destiny made this happen. & & & & \\
\hline 14. & Questioned the power of God & & & & \\
\hline
\end{tabular}




\section{APPENDIX III}

\section{Educational Stress Scale for Adolescent (ESSA) (SUN, Dunne, Hou and Xu 2010)}

This scale consists of 16 items describing the stress in your institution/college life from the various sources. The level of stress you feel for each item can be indicated by marking in the bracket given against each statement. If you feel No Stress put a mark in the 1 bracket(NS), Slight Stress in the 2(SS), Moderate Stress in the 3(MS), High Stress in the 4(HS) and you feel Extreme Stress put a mark in the 5 bracket(ES).

\section{$1=$ No Stress, $2=$ Slight Stress, $3=$ Moderate Stress, $4=$ High Stress, $5=$ Extreme Stress}

\begin{tabular}{|c|c|c|c|c|c|c|}
\hline No & Statement & 1 & 2 & 3 & 4 & 5 \\
\hline 1. & $\begin{array}{l}\text { There is too much competition among classmates } \\
\text { which brings me a lot of academic pressure. }\end{array}$ & & & & & \\
\hline 2. & I feel a lot of pressure in my daily studying. & & & & & \\
\hline 3. & $\begin{array}{l}\text { Future education and employment bring me a lot } \\
\text { of academic pressure }\end{array}$ & & & & & \\
\hline 4. & $\begin{array}{l}\text { My parents care about my academic grades too } \\
\text { much which brings me a lot of pressure }\end{array}$ & & & & & \\
\hline 5. & $\begin{array}{l}\text { I feel that I have disappointed my teacher when my } \\
\text { test/exam results are not ideal }\end{array}$ & & & & & \\
\hline 6. & $\begin{array}{l}\text { I feel that I have disappointed my parents when my } \\
\text { test/exam results are poor }\end{array}$ & & & & & \\
\hline 7. & $\begin{array}{l}\text { Academic grade is very important to my future and } \\
\text { even can determine my whole life }\end{array}$ & & & & & \\
\hline 8. & I am very dissatisfied with my academic grades & & & & & \\
\hline 9. & I always lack confidence with my academic scores & & & & & \\
\hline 10. & $\begin{array}{l}\text { It is very difficult for me to concentrate during } \\
\text { classes }\end{array}$ & & & & & \\
\hline 11. & $\begin{array}{l}\text { I feel stressed when I do not live up to my own } \\
\text { standards }\end{array}$ & & & & & \\
\hline 12. & $\begin{array}{l}\text { When I fail to live up to my own expectations, I } \\
\text { feel I am not good enough }\end{array}$ & & & & & \\
\hline 13. & $\begin{array}{l}\text { I usually cannot sleep and worry when I cannot } \\
\text { meet the goals I set for myself }\end{array}$ & & & & & \\
\hline 14. & I feel there is too much homework & & & & & \\
\hline 15. & I feel that there is too much school work & & & & & \\
\hline 16. & $\begin{array}{l}\text { I feel that there are too many tests /exams in the } \\
\text { school }\end{array}$ & & & & & \\
\hline
\end{tabular}

